\title{
Cell-surface location of Listeria-specific protein p60 - detection of Listeria cells by indirect immunofluorescence
}

\author{
Gerhard J. Ruhland, ${ }^{1}$ Manuela Hellwig, ${ }^{1}$ Gerhard Wanner ${ }^{2}$ and Franz Fiedler ${ }^{1 *}$ \\ ${ }^{1}$ Institut für Genetik und Mikrobiologie der Universität München, Maria-Ward-Str. 1a, 8000 München 19, FRG \\ ${ }^{2}$ Botanisches Institut der Universität München, Menzinger Strasse 67, 8000 München 19, FRG
}

(Received 18 September 1992; revised 23 October 1992; accepted 26 October 1992)

\begin{abstract}
A specific polyclonal antiserum was prepared against a gel-purified $60 \mathrm{kDa}$ extracellular protein of Listeria monocytogenes ATCC 19111 corresponding to protein p60 previously detected in culture broths of $L$. monocytogenes strains Mackaness and EGD [Kuhn, M. \& Goebel, W. (1989), Infection and Immunity 57, 55-61]. Indirect immunogold labelling combined with transmission electron microscopy and high-resolution scanning electron microscopy were used to investigate the location and distribution of p60 on the bacterial cell surface. In bacteria grown to the early stationary phase about $25 \%$ of the extracellular protein was estimated to be associated with the cell surface. The anti-p60 antiserum proved to be Listeria-specific. In an indirect immunofluorescence test the antiserum reacted with Listeria strains representing all species and different serotypes, except $L$. seeligeri, $L$. welshimeri, $L$. grayi and $L$. murrayi. No immunological cross-reactions were observed with 27 strains of bacteria from 16 other genera. The value of the anti-p60 antiserum in developing a diagnostic assay for Listeria cells in environmental samples and foods is discussed.
\end{abstract}

\section{Introduction}

Listeria monocytogenes is an opportunistic pathogen in humans and various animal species; $L$. ivanovii affects only the latter. The other species of the genus Listeria are avirulent. As a facultative intracellular parasite L. monocytogenes can penetrate and replicate within professional and nonprofessional phagocytic cells (Cossart \& Mengaud, 1989).

Cell surface components and extracellular proteins of $L$. monocytogenes are known to be involved in pathogenicity, e.g. by mediating adherence and penetration of the host cell. The cell surface of Listeria is composed of peptidoglycan, cell wall teichoic acids, lipoteichoic acids, and proteins (Fiedler et al., 1984; Fiedler \& Ruhland, 1987; Tabouret et al., 1992). Cowart et al. (1990) proposed that the attachment of a virulent Listeria strain to eukaryotic cells is mediated by the interaction of $\alpha$-Dgalactose residues exposed at the microbial cell surface with a eukaryotic galactose receptor. Lipoteichoic acids anchored to the outside of the cytoplasmic membrane were found to carry $\alpha$-D-galactosyl substituents probably involved in this process (Ruhland \& Fiedler, 1987). The presence of adhesins at the cell surface of L. mono-

\footnotetext{
*Author for correspondence. Tel. 89179198 52; fax 8917919849.
}

cytogenes was demonstrated using direct agglutination with neoglycoproteins (Cottin et al., 1990). Gaillard et al. (1991) identified an $80 \mathrm{kDa}$ cell surface protein (internalin) that mediates the entry of $L$. monocytogenes into nonprofessional phagocytic cells. A $60 \mathrm{kDa}$ protein (p60) detected in the culture fluid of $L$. monocytogenes probably participates in this process (Kuhn \& Goebel, 1989). Noninvasive rough mutants of $L$. monocytogenes forming long cell chains were found to be impaired in the synthesis of p60. Treatment of rough mutants with partially purified p60 led to disaggregation of cell chains and restored invasiveness. Listeriolysin $\mathrm{O}$, an $\mathrm{SH}-$ activated cytolysin secreted by $L$. monocytogenes, enables the bacterium to escape from the phagocytic vacuole of the infected cell (Gaillard et al., 1986; Kathariou et al., 1987; Tilney \& Portnoy, 1989). In the cytoplasm of the host cell $L$. monocytogenes interacts with the microfilament system, promoting intracellular movement and cell-to-cell spread (Tilney \& Portnoy, 1989; Dabiri et al., 1990). A $90 \mathrm{kDa}$ cell-surface protein was identified as a key component of this process (Kocks et al., 1992; Domann et al., 1992).

Listeria strains are widely distributed in nature, and Listeria-contaminated food (e.g. vegetables, dairy and meat products) was identified as the main source of infection in several outbreaks of listeriosis. Timeconsuming selective enrichment culture methods and 
physiological tests are currently used in the identification of Listeria (Hof, 1990). Recent outbreaks of listeriosis emphasize the need for more rapid and reliable detection procedures. The main interest has focused on genetic and immunoassay methods (Butman et al., 1988; McLauchlin et al., 1989; Köhler et al., 1990; Siragusa \& Johnson, 1990; Wang et al., 1991).

We have prepared a specific antiserum against the $60 \mathrm{kDa}$ extracellular protein (p60) of $L$. monocytogenes ATCC 19111 serotype 1/2a. Immunogold labelling combined with electron microscopy and an indirect immunofluorescence test were used to investigate whether p60 is a cell surface antigen which can be used for a rapid identification of Listeria cells.

\section{Methods}

Bacterial strains and growth conditions. The organisms used and their sources are listed in Table 1. Strains of Listeria spp., Jonesia denitrificans and Erysipelothrix rhusiopathiae were grown in brain/heart infusion broth (BHI, Oxoid) at $37^{\circ} \mathrm{C}$ unless otherwise stated. Lactobacilli were cultured in MRS broth $[10 \mathrm{~g}$ peptone (Oxoid), $5 \mathrm{~g}$ glucose, $4 \mathrm{~g}$ yeast extract (Oxoid), $2 \mathrm{~g} \mathrm{KH}_{2} \mathrm{PO}_{4}, 5 \mathrm{~g}$ sodium acetate, $2 \mathrm{~g}$ diammonium hydrogen citrate, $0.2 \mathrm{~g} \mathrm{MgSO}_{4} .7 \mathrm{H}_{2} \mathrm{O}, 0.05 \mathrm{~g}$ $\mathrm{MnSO}_{4} \cdot 4 \mathrm{H}_{2} \mathrm{O}$, and $1 \mathrm{ml}$ Tween 80 per litre, $\mathrm{pH} \mathrm{6.3-6.5]} \mathrm{at} 30^{\circ} \mathrm{C}$, and Enterococcus faecalis in antibiotic medium 3 (Oxoid) at $37^{\circ} \mathrm{C}$. Coryneform organisms were grown in a medium composed of $\left(1^{-1}\right)$ : $17 \mathrm{~g}$ casein peptone (Oxoid), $3 \mathrm{~g}$ soya peptone (Oxoid), $5 \mathrm{~g}$ yeast extract (Oxoid), $2.5 \mathrm{~g}$ glucose, $5 \mathrm{~g} \mathrm{NaCl}, 2.5 \mathrm{~g} \mathrm{~K}_{2} \mathrm{HPO}_{4}$ and $1 \mathrm{ml}$ Tween 80 $\left(\mathrm{pH} \mathrm{7.3)}\right.$ at $30^{\circ} \mathrm{C}$. The remaining organisms were grown in nutrient broth containing $\left(\mathrm{l}^{-1}\right): 5 \mathrm{~g}$ glucose, $5 \mathrm{~g}$ yeast extract (Oxoid), $10 \mathrm{~g}$ tryptone (Oxoid) and $5 \mathrm{~g} \mathrm{NaCl}, \mathrm{pH} \mathrm{7.5}$. The growth temperature was $37^{\circ} \mathrm{C}$ for the Staphylococcus spp., Escherichia coli, Salmonella typhimurium and Streptococcus thermophilus and $30^{\circ} \mathrm{C}$ for the other organisms. Er. rhusiopathiae, Lactobacillus spp., Ent. faecalis and Strep. thermophilus were grown without aeration, the other strains were cultured aerobically with shaking.

Preparation of extracellular proteins. BHI broth was filtered in an Amicon ultrafiltration cell through a YM 10 membrane to remove high-molecular-mass compounds (e.g. large polypeptides). Strains of Listeria spp. were grown in the filtrate to the early stationary phase; the optical density at $580 \mathrm{~nm}\left(\mathrm{OD}_{580}\right)$ corresponded to approximately $2 \cdot 0$. Bacteria were harvested by centrifugation $\left(14000 \mathrm{~g}\right.$ for $\left.30 \mathrm{~min}, 4^{\circ} \mathrm{C}\right)$. The pellet was heated at $100^{\circ} \mathrm{C}$ for $15 \mathrm{~min}$, washed twice with PBS $(0.02 \mathrm{M}$-sodium phosphate, $\mathrm{pH} 7.2,0.9 \% \mathrm{NaCl})$, lyophilized, and weighed. The culture supernatant was filter-sterilized $(0 \cdot 2 \mu \mathrm{m}$ pore diameter, Sartorius) and subsequently concentrated 100 -fold in an Amicon ultrafiltration cell using a YM 30 membrane. The filtered supernatant was diluted twice $(1 / 10)$ in the cell with double-distilled water and concentrated again. All the treatments were performed at $4^{\circ} \mathrm{C}$.

Preparation of antisera. An antiserum was raised in a female rabbit against gel-purified samples of a $60 \mathrm{kDa}$ exoprotein of L. monocytogenes ATCC 19111 serogroup 1/2a. The identity of the $60 \mathrm{kDa}$ protein with $\mathrm{p} 60$ was established by immunoblotting using an antiserum against p60 derived from the non-haemolytic mutant $L$. monocytogenes M20 (Köhler et al., 1990). The culture supernatant proteins were separated by SDS-PAGE $(6 \%, \mathrm{w} / \mathrm{v}$, polyacrylamide $)$ and visualized in $1 \mathrm{M}-\mathrm{KCl}\left(4^{\circ} \mathrm{C}, 16 \mathrm{~h}\right)$. The protein was recovered from carefully excised bands by electroelution using a Biotrap electro-separation system (Schleicher \& Schüll). Prior to immunization, the rabbit was examined for the absence of antibodies reacting with extracellular proteins of L. monocytogenes ATCC 19111 by immunoblotting. The protein preparation for primary injection was emulsified in complete Freund's adjuvant. Subsequent booster injections, with incomplete Freund's

Table 1. Bacterial strains

\begin{tabular}{|c|c|c|}
\hline Species & Strain* & Serotype \\
\hline Listeria monocytogenes & ATCC19111 & $1 / 2 \mathrm{a}$ \\
\hline L. monocytogenes & $\operatorname{SLCC~} 5782^{a}$ & $1 / 2 a$ \\
\hline L. monocytogenes & ATCC 19113 & $3 \mathrm{a}$ \\
\hline L. monocytogenes & ATCC 19115 & $4 b$ \\
\hline L. monocytogenes & SLCC $5778^{b}$ & $4 b$ \\
\hline L. monocytogenes & SLCC 2482 & 7 \\
\hline L. ivanovii & ATCC 19119 & 5 \\
\hline L. innocua & ATCC 33090 & $6 \mathrm{a}$ \\
\hline L. innocua & ATCC 33091 & $6 \mathrm{~b}$ \\
\hline L. seeligeri & SLCC 3954 & $1 / 2 b$ \\
\hline L. welshimeri & SLCC 5334 & $6 a$ \\
\hline L. grayi & ATCC 25401 & \\
\hline L. murrayi & ATCC 19120 & \\
\hline \multicolumn{3}{|l|}{ Bacillus subtilis $\dagger$} \\
\hline Brevibacterium linens & ATCC 19391 & \\
\hline$B b$. linens & Ac $831^{c}$ & \\
\hline Bb. linens & Ac $577^{c}$ & \\
\hline Bb. linens & Ac $480^{c}$ & \\
\hline Brochothrix thermosphacta & DSM 20171 & \\
\hline Coryneform organism & $\mathrm{CNRZ} 925^{d}$ & \\
\hline Coryneform organism & $\mathrm{CNRZ} 926^{d}$ & \\
\hline \multicolumn{3}{|l|}{ Enterobacter aerogenes $\dagger$} \\
\hline Enterococcus faecalis & $\mathrm{DS} 16^{e}$ & \\
\hline Enterococcus faecalis & $\mathrm{OG}_{1} \mathrm{~S}^{e}$ & \\
\hline $\begin{array}{l}\text { Erysipelothrix rhusiopathiae } \\
\text { Escherichia coli } \dagger\end{array}$ & NCTC 8163 & \\
\hline Jonesia denitrificans & ATCC 14870 & \\
\hline Lactobacillus casei & DSM 20011 & \\
\hline Lb. curvatus & DSM 20019 & \\
\hline Lb. plantarum & DSM 20174 & \\
\hline Micrococcus luteus & DSM 20030 & \\
\hline Pseudomonas aeruginosa & ATCC 27853 & \\
\hline Salmonella typhimurium & $\mathbf{L T} 2^{f}$ & \\
\hline Serratia marcescens & DSM 30121 & \\
\hline \multicolumn{3}{|l|}{ Staphylococcus aureus $\mathrm{H} \dagger$} \\
\hline Staph. aureus Copenhagen & DSM 20232 & \\
\hline Staph. saprophyticus & DSM 20229 & \\
\hline Staph. epidermidis & DSM 20044 & \\
\hline Staph. xylosus & DSM 20266 & \\
\hline Streptococcus thermophilus & NCDO 573 & \\
\hline
\end{tabular}

* ATCC, American Type Culture Collection, Rockville, Md, USA; DSM, Deutsche Sammlung von Mikroorganismen, Braunschweig, FRG; SLCC, Special Listeria Culture Collection, Würzburg, FRG; NCDO, National Collection of Diary Organisms, Reading, UK; NCTC, National Collection of Type Cultures, London, UK; CNRZ, Centre National de Recherches Zootechniques, Jouy-en-Josas, France. ${ }^{a, b}$ Vaccine strains from Prof. Dr J. Potel, Hannover, FRG (rough mutants forming long cell chains; derived from serotype $1 / 2 \mathrm{a}$, original no. 32/46J, and serotype $4 \mathrm{~b}$, original no. 1345 , respectively). ${ }^{c}$ From $\mathrm{Dr}$ W. H. J. Crombach, Microbiology Laboratory, Agricultural University of Wageningen, The Netherlands. ${ }^{d}$ Isolates from the surface of French cheese, provided by Dr J.P. Accolas (Station Centrale des Recherches Laitières et de Technologie des Produits Animaux, Jouy-en-Josas, France). ${ }^{e}$ From Dr R. Wirth, Institut für Genetik und Mikrobiologie, Universität München, FRG. ${ }^{f}$ From Prof. Dr H. Schmieger, Institute für Genetik und Mikrobiologie, Universität München, FRG.

$\dagger$ Culture collection of the Institut für Genetik und Mikrobiologie, Universität München, FRG. 
adjuvant, were given 4 and 6 weeks after the first immunization. The rabbit was injected intradermally at multiple sites with approximately $60 \mu \mathrm{g}$ protein per immunization. The animal was bled, and antiserum prepared, $12 \mathrm{~d}$ after the third injection. For control experiments an anti-listeriolysin $\mathrm{O}$ antiserum was prepared in the same way.

Immunogold labelling of cells and electron microscopy. Cells corresponding to $1 \mathrm{ml}$ of an overnight culture in BHI broth were washed with $1.5 \mathrm{ml}$ PBS immediately after harvesting. For indirect immunogold labelling the cells were resuspended in $1 \mathrm{ml}$ PBS containing $1 \mathrm{~mm}-$ sodium azide and the anti-p60 antiserum (dilution: 1/250). The suspension was incubated for $2 \mathrm{~h}$ at room temperature with gentle agitation. Cells were then washed twice with $1.5 \mathrm{ml}$ PBS and resuspended in $1 \mathrm{ml}$ of the same buffer. After the addition of $300 \mu \mathrm{l}$ Auro Probe EM (gold-labelled protein A with a mean particle size of $10 \mathrm{~nm}$, Janssen Biotech) the cell/immunogold suspension was mixed carefully for $3 \mathrm{~h}$ at room temperature. The cells were separated by centrifugation $(8000 \mathrm{~g}, 10 \mathrm{~min})$, washed twice with $1.5 \mathrm{ml} \mathrm{PBS}$, and fixed for electron microscopy (Wanner et al., 1989). Transmission and high-resolution scanning electron microscopy were performed as described by Wanner et al. (1989).

Indirect immunofluorescence antibody test. This was carried out as described by Walker et al. (1971). Cells were grown overnight in BHI broth, heat killed $\left(100^{\circ} \mathrm{C}, 15 \mathrm{~min}\right)$ and washed once with doubledistilled water. The cells were resuspended in double-distilled water, applied to slides, air-dried, and heat-fixed. The samples were incubated with the anti-p60 antiserum, diluted in Tris-buffered saline (TBS; $0.1 \mathrm{M}$ Tris/ $\mathrm{HCl}, \mathrm{pH} 7 \cdot 4,0.9 \% \mathrm{NaCl}$ ) as indicated in Table 2 , for $1 \mathrm{~h}$ at room temperature in a humid chamber. The slides were washed six times with TBS and dried with filter paper. The fixed cells were labelled with antirabbit IgG-fluorescein isothiocyanate conjugate (FITC, Sigma) at a $1 / 20$ dilution in TBS and incubated for $30 \mathrm{~min}$ at room temperature in a humid chamber. The slides were washed again six times with TBS and dried with filter paper. The samples were mounted under a coverslip in $0.5 \mathrm{M}$-sodium carbonate-buffered glycerol $(1: 9, \mathrm{v} / \mathrm{v}), \mathrm{pH} 9 \cdot 0$, and examined by fluorescence microscopy. Controls were treated with preimmune serum or TBS buffer instead of the anti-p60 antiserum.

SDS-PAGE and immunoblotting. SDS-PAGE was performed in stacking gels with $4 \%(\mathrm{w} / \mathrm{v})$ and separating gels with 6 or $10 \%(\mathrm{w} / \mathrm{v})$ polyacrylamide according to Laemmli (1970). Gels (1 mm thickness) were prepared using a minigel apparatus $(8 \times 8 \mathrm{~cm}$, Biometra). Cellassociated protein was analysed by boiling lyophilized and PBS-washed cells in SDS-sample buffer for $5 \mathrm{~min}$. Cells were removed by centrifugation $(8000 \mathrm{~g}, 10 \mathrm{~min})$ and the supernatant (SDS extract) was applied to the gel. Protein bands on the gels were visualized with Coosmassie Brilliant Blue R250. Electrophoretic transfer of proteins to nitrocellulose membranes was carried out as described by Towbin $e t$ al. (1979). Proteins reacting with the anti-p60 antiserum were visualized by subsequent incubation of the filter with anti-rabbit IgG-peroxidase conjugate (Sigma) and diaminobenzidine $/ \mathrm{H}_{2} \mathrm{O}_{2}$. Alternatively, ${ }^{125}$ I-protein A (Amersham Buchler) and autoradiography on Kodak $\mathrm{X}$-ray film were used to detect reacting proteins. For quantification, the immunoreactive bands on nitrocellulose filters were excised and measured in Rotiszint 11 (Carl Roth) using a liquid scintillation counter (Kontron MR 300).

\section{Results}

\section{Immunoblot analysis of culture supernatants}

The extracellular protein pattern of $L$. monocytogenes ATCC 19111 serotype 1/2a obtained by SDS-PAGE is shown in Fig. 1(a) (lane 2). The most prominent bands (a)

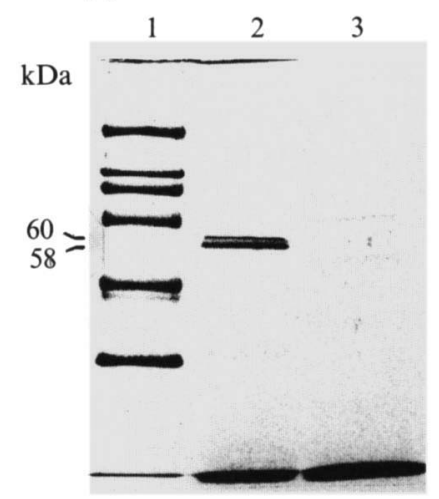

(b)

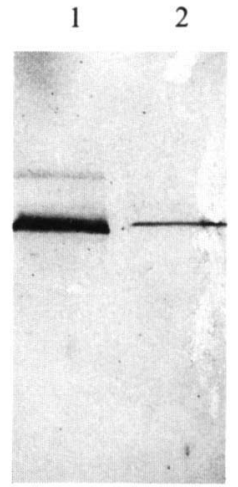

Fig. 1. SDS-PAGE and immunoblot analysis of extracellular proteins from $L$. monocytogenes serotype $1 / 2 \mathrm{a}$ grown at $37^{\circ} \mathrm{C}(a)$. Coomassiestained $10 \%$ SDS-PAGE gel of culture supernatants from L. monocytogenes ATCC 19111 (lane 2) and L. monocytogenes SLCC 5782 (lane 3). Lane 1 contains molecular mass standards (from top to bottom, 205, 116, 97.4, 66, 45, and $29 \mathrm{kDa}$ ). (b). Immunoblot analysis of extracellular proteins of $L$. monocytogenes ATCC 19111 (lane 1) and L. monocytogenes SLCC 5782 (lane 2) with anti-p60 antiserum diluted $1 / 200000$. Immunoreacting proteins were visualized on nitrocellulose membranes using anti-rabbit IgG-peroxidase conjugate. Extracellular proteins corresponding to $1 \mathrm{mg}$ dry cells were applied in $(a)$ and $(b)$.

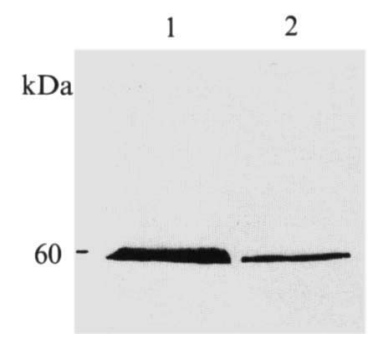

Fig. 2. Immunoblot analysis of culture supernatants from L. monocytogenes ATCC 19111 grown at $37^{\circ} \mathrm{C}$ (lane 1) and $26^{\circ} \mathrm{C}$ (lane 2) with anti-p60 antiserum. Antibody binding was visualized using antirabbit IgG-peroxidase conjugate. Extracellular proteins corresponding to $1 \mathrm{mg}$ dry cells were applied to each lane.

correspond to listeriolysin $(58 \mathrm{kDa})$ and protein $\mathrm{p} 60$, as shown by Kuhn \& Goebel (1989) for other haemolytic L. monocytogenes strains.

Immunoblot analysis of culture supernatant of L. monocytogenes ATCC 19111 revealed that the antip60 antiserum reacted strongly with protein p60 (Fig. $1 b$, lane 1). However, an additional weakly reacting protein with an apparent molecular mass of about $110 \mathrm{kDa}$ was visible. This band was also detected when p60 excised from a gel was reanalysed by SDS-PAGE and subsequent immunoblotting. This indicated that the $110 \mathrm{kDa}$ protein band was derived from p60, most probably due to aggregation. In the culture supernatant of the rough 

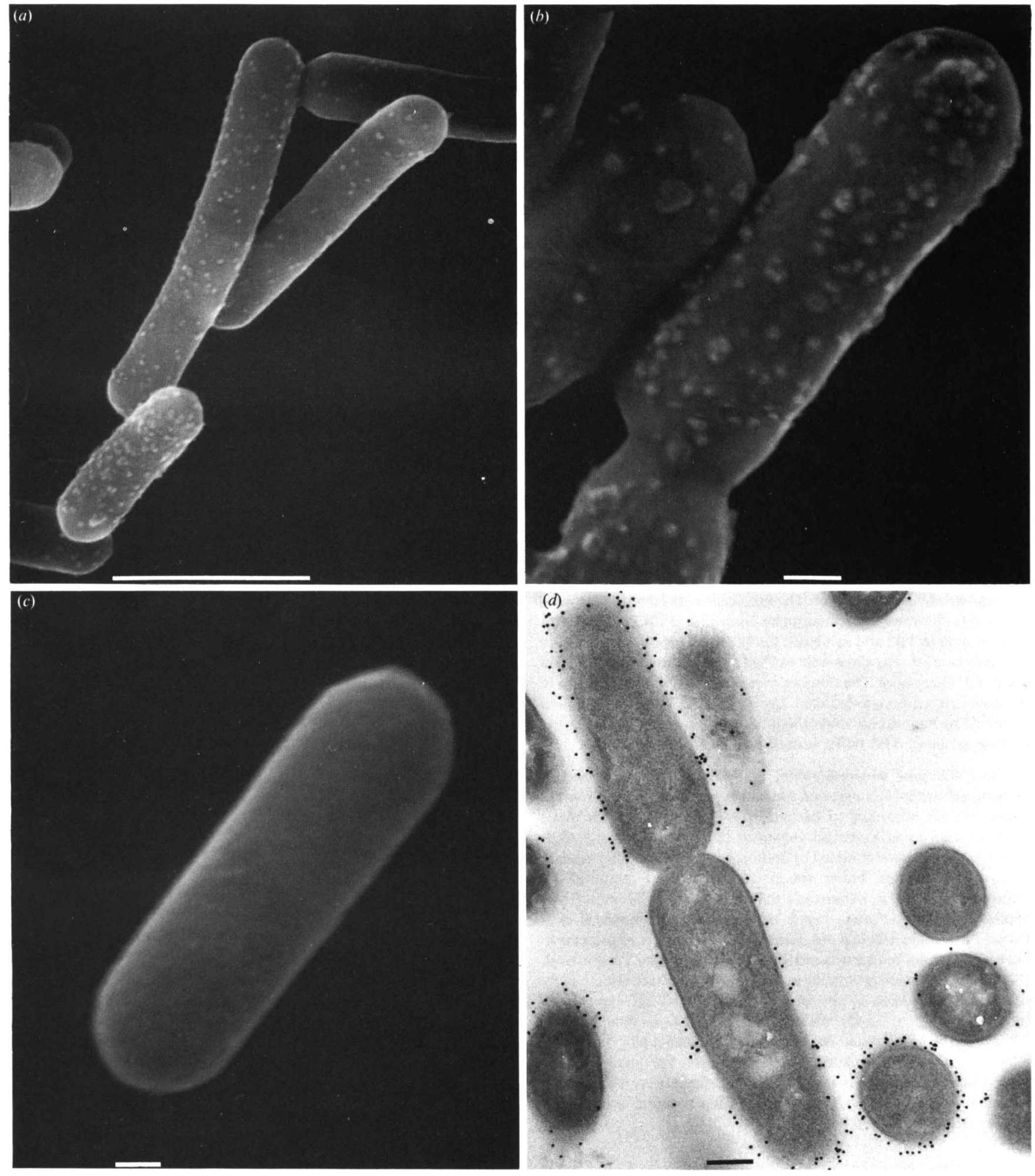

Fig. 3. High-resolution scanning electron micrographs $(a-c)$ and transmission electron micrograph of an ultrathin section $(d)$ of L. monocytogenes ATCC 19111. Prior to immunogold labelling (diameter of gold particles $10 \mathrm{~nm}$ ), cells were incubated with anti-p60 antiserum $(a, b$ and $d)$ or pre-immune serum $(c)$. Note that the immunogold label is uniformly distributed over the cell surface in $(a)$, $(b)$ and $(d)$ but totally absent in the control $(c)$. Bars, $1 \mu \mathrm{m}$ in $(a) ; 100 \mathrm{~nm}$ in $(b)-(d)$. 

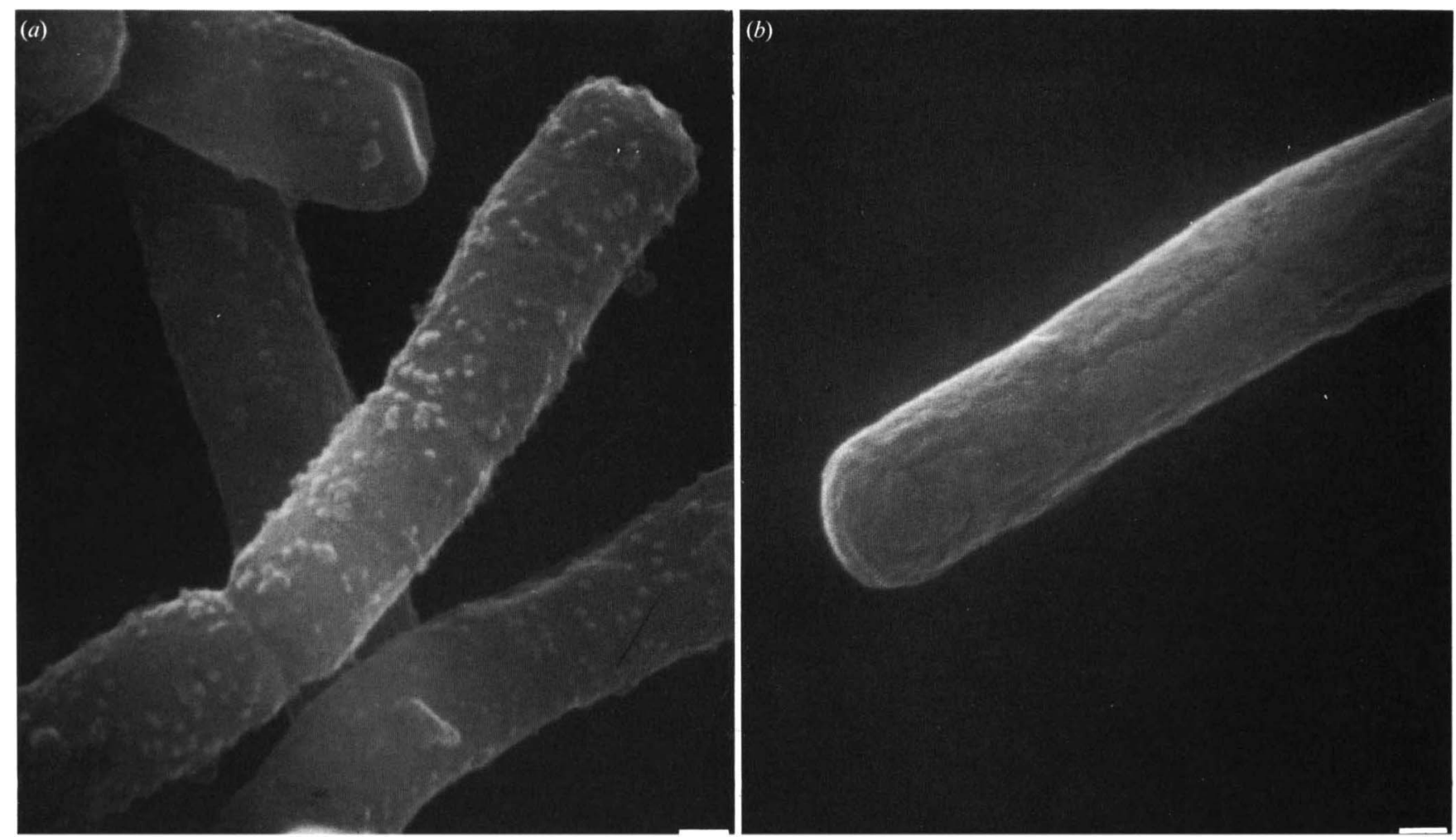

Fig. 4. High-resolution scanning electron micrographs of $L$. monocytogenes SLCC 5782. Prior to immunogold labelling, cells were incubated with anti-p60 antiserum $(a)$ or pre-immune serum $(b)$. The cell surface is uniformly labelled in $(a)$. Immunogold labelling is absent in the control $(b)$. Bars, $100 \mathrm{~nm}$.

mutant, L. monocytogenes SLCC 5782, p60 was detected with the anti-p60 antiserum (Fig. $1 b$, lane 2); however, the concentration of the protein was too low to be visualized in Coomassie-stained SDS-polyacrylamide gels (Fig. 1 $a$, lane 3).

Culture supernatants from various strains of Listeria spp. (Table 1) were analysed by immunoblotting with anti-p60 antiserum. Proteins immunologically related to p60 with a similar molecular mass were detected in all strains except $L$. grayi and $L$. murrayi (data not shown). In the case of $L$. seeligeri and $L$. welshimeri, however, only a weak reaction was observed.

Production of $\mathrm{p} 60$ by L. monocytogenes ATCC 19111 was examined at 26 and $37^{\circ} \mathrm{C}$. Immunoblot analysis of supernatants prepared from early stationary phase cultures indicated that cells grown at $26^{\circ} \mathrm{C}$ produced much less p60 than those grown at $37^{\circ} \mathrm{C}$ (Fig. 2).

\section{Cell surface location of protein p60}

L. monocytogenes ATCC 19111 and the rough mutant L. monocytogenes SLCC 5782 were investigated for cell surface association of protein p60. High-resolution scanning electron microscopy revealed that cells of both the wild-type and the mutant strain exhibited immunogold label after successive treatment with the anti-p60 antiserum and protein A-gold complex (Figs $3 a, b$ and $4 a$ ). The immunogold particles were not restricted to particular areas, but were distributed uniformly over the cell surface. This was confirmed by transmission electron microscopy of an ultrathin section of immunogold-labelled cells (Fig. $3 d$ ). The maximum density of gold grains on the cell surface was estimated to be about 300 per $\mu \mathrm{m}^{2}$ for both ATCC 19111 and the rough mutant SLCC 5782. The specificity of immunogold labelling was established by control experiments in which the anti-p60 antiserum was replaced by either pre-immune serum or the antilisteriolysin antiserum. High-resolution scanning electron micrographs demonstrated that these cells were totally free of gold particles (Figs $3 c$ and $4 b$ ).

These findings clearly indicated that protein $\mathrm{p} 60$, at first detected in the culture supernatant, was also located at the cell surface, whereas listeriolysin did not appear to be associated with the cell.

\section{Quantification of cell-associated and cell-free p60}

Cell surface associated protein p60 was not released from the cells by boiling for $10 \mathrm{~min}$, washing with PBS, or extraction with $5 \mathrm{M}-\mathrm{LiCl}$ (data not shown). However, the protein was removed when PBS-washed cells were 
Table 2. Reactivity of the anti-p60 antiserum in the indirect immunofluorescence test

\begin{tabular}{lccccccc}
\hline \hline & \multicolumn{7}{c}{ Dilution of antiserum } \\
\cline { 2 - 7 } \multicolumn{1}{c}{ Bacterial strain } & $1 / 32$ & $1 / 64$ & $1 / 128$ & $1 / 256$ & $1 / 512$ & $1 / 1024$ \\
\hline Listeria monocytogenes ATCC 19111 & + & + & + & + & + & - \\
L. monocytogenes SLCC 5782* & + & + & + & - & - & - \\
L. monocytogenes ATCC 19113 & + & + & + & + & - & - \\
L. monocytogenes ATCC 19115 & + & + & - & - & - & - \\
L. monocytogenes SLCC 5778* & + & + & + & - & - & - \\
L. monocytogenes SLCC 2482 & + & + & - & - & - & - \\
L. ivanovii ATCC 19119 & + & + & - & - & - & - \\
L. innocua ATCC 33090 & + & + & + & - & - & - \\
L. innocua ATCC 33091 & + & - & - & - & - & - \\
L. seeligeri SLCC 3954 & - & - & - & - & - & - \\
L. welshimeri SLCC 5334 & - & - & - & - & - & - \\
L. grayi ATCC 25401 & - & - & - & - & - & - \\
L. murrayi ATCC 19120 & - & - & - & - & - & - \\
Staphylococcus aureus H & + & + & + & + & + & + \\
Staph. aureus Copenhagen & + & + & + & + & + & + \\
Other bacterial strains $\dagger$ & - & - & - & - & - & - \\
\hline \hline & & + &
\end{tabular}

* Rough mutants.

$\dagger$ See Table 1.

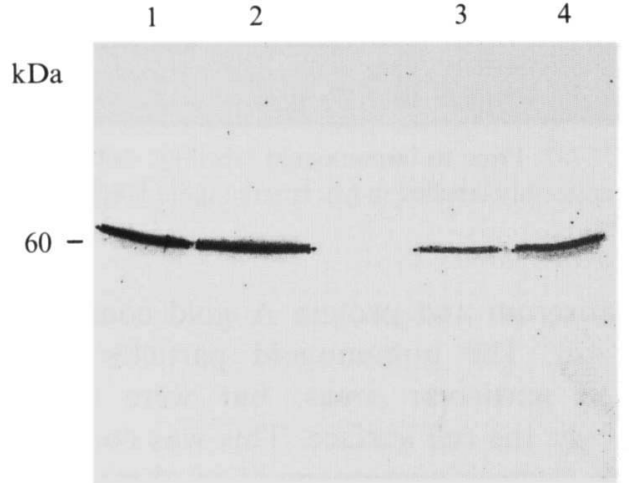

Fig. 5. Immunoblot analysis of L. monocytogenes ATCC 19111 culture supernatants (lanes 1 and 2) and SDS extracts of whole cells (lanes 3 and 4) with anti-p60 antiserum. Immunoreacting proteins were visualized with ${ }^{125} \mathrm{I}$-protein $\mathrm{A}$ and autoradiography. Samples corresponding to $1 \mathrm{mg}$ (lanes 1 and 3) or $2 \mathrm{mg}$ (lanes 2 and 4) dry cells were applied. For quantification of the immunoreaction, radioactive bands were excised from the nitrocellulose filter and their radioactivity measured.

boiled in SDS-sample buffer. This SDS extract and the culture supernatant were analysed by immunoblotting using the anti-p60 antiserum and ${ }^{125} \mathrm{I}$-protein A (Fig. 5). The radioactivity of the immunoreactive bands was measured and the ratio of cell-bound (Fig. 5, lanes 3 and 4) to free protein (Fig. 5, lanes 1 and 2) was calculated to be 0.24 and 0.23 , respectively. This would mean that about $25 \%$ of p60 was located at the cell surface.

\section{Specificity of the anti-p60 antiserum}

The antiserum raised against protein p60 of L. monocytogenes ATC 19111 was examined in an indirect immunofluorescence assay with 13 strains of Listeria, representing all species and different serotypes, as well as two rough mutants of $L$. monocytogenes. Twenty seven strains from 16 other genera were also investigated (Table 1). The anti-p60 antiserum (dilution $>1 / 32$ ) reacted with all Listeria strains tested, except $L$. seeligeri, L. welshimeri, L. grayi and L. murrayi (Table 2). The reaction of the rough mutants was quite similar to that of the wild-type strains. With cells of $L$. monocytogenes grown at $26{ }^{\circ} \mathrm{C}$ instead of $37^{\circ} \mathrm{C}$ a positive, but less intense, reaction was obtained (data not shown). None of the strains from the other genera, except the Staph. aureus strains, were labelled in the indirect immunofluorescence assay with anti-p60 antiserum (Table 2).

In a further experiment, cells of $L$. monocytogenes ATCC 19111 harvested in the early $\left(\mathrm{OD}_{580} 0.42\right)$, middle $\mathrm{OD}_{580}$ 0.95), and late exponential growth phase $\left(\mathrm{OD}_{580}\right.$ 1.90) were examined in the indirect immunofluorescence test. A positive reaction with cells was observed in all cases, although p60 was not detected in culture supernatants of the early and middle exponential growth phase (data not shown). The antiserum prepared against listeriolysin $\mathrm{O}$, however, did not react when tested with L. monocytogenes ATCC 19111, although this protein is secreted in large amounts in comparison to p60 (Fig. 1 a).

\section{Discussion}

Protein p60 was originally detected in the culture supernatant of L. monocytogenes by Kuhn \& Goebel (1989). Our immunological data provide evidence that a portion of p60 is associated with the cell surface of L. monocytogenes. Since the antiserum was elicited with the purified protein together with Freund's complete 
adjuvant it could also contain antibodies against fragments of the mycobacterial cell wall causing an unspecific reactivity. This, however, could be excluded because an antiserum raised against purified listeriolysin O, also with Freund's complete adjuvant, did not react with the cell surface of $L$. monocytogenes.

In an early stationary phase culture of L. monocytogenes ATCC 19111, about $25 \%$ of p60 was cellassociated. Interestingly, the rough mutant $L$. monocytogenes SLCC 5782, which is impaired in the secretion of p60, was found to carry the protein uniformly distributed over the cell surface. Assuming that the quantity of gold particles counted approximately represents the actual number of protein molecules, the maximum density of molecules was identical for both the wild-type strain and the rough variant. Detailed experiments to determine how p60 is attached to the cell surface were not performed. The observation that the protein was not extracted with $5 \mathrm{M}-\mathrm{LiCl}$ may suggest that hydrophobic rather than ionic interactions play a prominent role in the attachment.

Kuhn \& Goebel (1989) showed that p60 participates in the invasion of nonprofessional phagocytic cells by $L$. monocytogenes. Treatment of a noninvasive rough mutant of $L$. monocytogenes serotype $1 / 2$ a with partially purified $\mathrm{p} 60$ resulted in restoration of invasiveness. Since the rough mutant and the wild-type strain of L. monocytogenes did not differ in the amount of cellsurface-bound p60, the secreted form of the protein seems to be necessary in the invasion of nonprofessional phagocytes.

Recently, Köhler et al. (1990, 1991) analysed expression of the gene encoding $\mathrm{p} 60$ of $L$. monocytogenes 1/2a EGD and the rough variant $L$. monocytogenes RIII. They found equal amounts of p60-specific mRNA in both the wild-type and the mutant strain, indicating control at the post-transcriptional level by a specific factor that is defective in the mutant strain. According to our data, the reduced expression of p60 in rough mutants only affected the amount of secreted, but not cell surface associated p60. Leimeister-Wächter et al. (1992) reported that expression of listeriolysin $\mathrm{O}$ and other virulence factors is repressed at lower growth temperatures. We found that the concentration of $\mathrm{p} 60$ in the culture supernatant of L. monocytogenes ATCC 19111 was lower at $26^{\circ} \mathrm{C}$ than at $37^{\circ} \mathrm{C}$, implying thermoregulated expression. Cells grown at the lower temperature also exhibited a less intense reaction with the anti-p60 antiserum, indicating a reduced amount of cell surface associated $\mathrm{p} 60$.

Hybridization experiments with the gene encoding protein p60 indicated the presence of homologous DNA sequences in Listeria species except $L$. grayi and L. murrayi (Köhler et al., 1990; Flamm et al., 1989). Our indirect immunofluorescence data provide evidence that the immunologically cross-reactive proteins are also exposed at the cell surface. The antiserum reacted significantly with all strains of $L$. monocytogenes, $L$. ivanovii and $L$. innocua investigated but not with the species $L$. seeligeri, $L$. welshimeri, $L$. grayi and $L$. murrayi. These data correlate with the results obtained by immunoblot analysis of the culture supernatants, where $L$. grayi and $L$. murrayi showed no reaction, and $L$. seeligeri and $L$. welshimeri only a very weak reaction. No cross-reactivity of the antiserum was observed with 27 non-Listeria strains representing 16 different genera, except Staph. aureus strains. The positive reaction of Staph. aureus strains, however, is most probably not immunospecific but may be explained by the presence of $F_{c}$ receptors (protein $A$ ) on the cell surface (Forsgren \& Forsum, 1970). The anti-p60 antiserum reacted with cells of L. monocytogenes grown at both $37^{\circ} \mathrm{C}$ and $26^{\circ} \mathrm{C}$, and with bacteria obtained from different growth phases in batch culture. Hence protein p60 seems to be a stably expressed cell surface antigen.

In the last few years, preparations of various Listeriaspecific monoclonal antibodies have been reported (Butman et al., 1988; McLauchlin et al., 1989; Siragusa \& Johnson, 1990), although little is known about the corresponding antigens. However, a monoclonal antibody recognizing a $66 \mathrm{kDa}$ cells surface antigen of L. monocytogenes was reported by Bhunia \& Johnson (1992). We have now defined protein p60 as a Listeriaspecific cell-wall-associated antigen. The reaction of the anti-p60 antiserum seems to be restricted to strains belonging to the human and animal pathogenic species $L$. monocytogenes and $L$. ivanovii, except in the case of the avirulent $L$. innocua strains.

We suggest that the antiserum prepared against protein $\mathrm{p} 60$ of $L$. monocytogenes is suitable for developing a specific immunoassay (e.g. immunofluorescence test) for detecting Listeria strains. Since it is well known that the cell surface composition of bacteria may change with culture conditions (Brown \& Williams, 1985), it is necessary to determine whether the anti-p60 antiserum also reacts with Listeria strains obtained from environmental samples or foods.

We thank Drs J. Kreft and S. Köhler (Institut für Genetik und Mikrobiologie, Universität Würzburg, FRG) for performing the control immunoblot experiment with culture supernatant of L. monocytogenes ATCC 19111 and anti-p60 antiserum derived from the non-haemolytic mutant $L$. monocytogenes M20.

\section{References}

Brown, M. R. W. \& Williams, P. (1985). The influence of environment on envelope properties affecting survival of bacteria in infections. Annual Review of Microbiology 39, 527-556.

BuHNiA, A. K. \& Johnson, M. G. (1992). Monoclonal antibody specific for Listeria monocytogenes associated with a 66-kilodalton cell 
surface antigen. Applied and Environmental Microbiology 58, 1924-1929.

Butman, B. T., Plank, M. C., Durham, R. J. \& Mattingly, J. A. (1988). Monoclonal antibodies which identify a genus-specific Listeria antigen. Applied and Environmental Microbiology 54, $1564-1569$.

Cossart, P. \& Mengaud, J. (1989). Listeria monocytogenes - a model system for the molecular study of intracellular parasitism. Molecular Biology and Medicine 6, 463-474.

Cottin, J., Loiseau, O., Robert, R., Mahaza, C., Carbonnelle, B. \& SENET, J. M. (1990). Surface Listeria monocytogenes carbohydratebinding components revealed by agglutination with neoglycoproteins. FEMS Microbiology Letters 68, 301-306.

CowarT, R. E., Lashmet, J., McIntosh, M. E. \& Adams, T. J. (1990). Adherence of a virulent strain of Listeria monocytogenes to the surface of a hepatocarcinoma cell line via lectin-substrate interaction. Archives of Microbiology 153, 282-286.

Dabiri, G. A., Sanger, J. M., Portnoy, D. A. \& Southwick, F. S. (1990). Listeria monocytogenes moves rapidly through the host-cell cytoplasm by inducing directional actin assembly. Proceedings of the National Academy of Sciences of the United States of America 87, 6068-6072.

Domann, E., Wehland, J., Rohde, M., Pistor, S., Hartl, M., GOEBel, W., Leimeister-WÄCHTER, M., WUeNSCHER, M. \& Chakraborty, T. (1992). A novel bacterial virulence gene in Listeria monocytogenes required for host cell microfilament interaction with homology to the proline-rich region of vinculin. EMBO Journal 11, 1981-1990.

FiEdler, F. \& RuHland, G. J. (1987). Structure of Listeria monocytogenes cell walls. Bulletin Institute Pasteur 85, 287-300.

Fiedler, F., Seger, J., SchrettenbrunNer, A. \& Seeliger, H. P. R. (1984). The biochemistry of murein and cell wall teichoic acids in the genus Listeria. Systematic and Applied Microbiology 5, 360-376.

Flamm, R. K., Hinrichs, D. J. \& Thomashow, M. F. (1989). Cloning of a gene encoding a major secreted polypeptide of Listeria monocytogenes and its potential use as a species-specific probe. Applied and Environmental Microbiology 55, 2251-2256.

FoRSGREN, A. \& FORSUM, U. (1970). Role of protein A in nonspecific immunofluorescence of Staphylococcus aureus. Infection and Immunity 2, 387-391.

Gaillard, J. L., Berche, P. \& Sansonetti, P. (1986). Transposon mutagensis as a tool to study the role of hemolysin in the virulence of Listeria monocytogenes. Infection and Immunity 52, 50-55.

Gaillard, J.-L., Berche, P., Frehel, C., Gouin, E. \& Cossart, P. (1991). Entry of L. monocytogenes into cells is mediated by internalin, a repeat protein reminiscent of surface antigens from gram-positive cocci. Cell 65, 1127-1141.

HoF, H. (1990). Listerien - eine Herausforderung für die Diagnostik. Immunität und Infektion 18, 35-39.

Kathariou, S., Metz, P., Hof, H. \& Goebel, W. (1987) Tn916-induced mutations in the hemolysin determinant affecting virulence of Listeria monocytogenes. Journal of Bacteriology 169, 1291-1297.

Kocks, C., Gouin, E., Tabouret, M., Berche, P., Ohayon, H. \& Cossart, P. (1992). L. monocytogenes-induced actin assembly requires the act $A$ gene product, a surface protein. Cell 68, 521-531.

KÖHLER, S., LeIMEISTER-WÄCHTER, M., CHAKRABORTY, T., LOTTSPEICH, F. \& GoEBEL, W. (1990). The gene coding for protein p60 of Listeria monocytogenes and its use as a specific probe for Listeria monocytogenes. Infection and Immunity 58, 1943-1950.

Köhler, S., Bubert, A., Vogel, M. \& Goebel, W. (1991). Expression of the iap gene coding for protein p60 of Listeria monocytogenes is controlled on the posttranscriptional level. Journal of Bacteriology 173, 4668-4674.

KuHN, M. \& GoEBeL, W. (1989). Identification of an extracellular protein of Listeria monocytogenes possibly involved in intracellular uptake by mammalian cells. Infection and Immunity 57, 55-61.

LAEMMLI, U. K. (1970). Cleavage of structural proteins during the assembly of the head of bacteriophage T4. Nature, London 227 , 680-685.

Leimeister-Wächter, M., DomanN, E. \& Chakraborty, T. (1992). The expression of virulence genes in Listeria monocytogenes is thermoregulated. Journal of Bacteriology 174, 947-952.

Mclauchlin, J., Ridley, A. M. \& TaYloR, A. G. (1989). The use of monoclonal antibodies against Listeria monocytogenes in a direct immunofluorescence technique for the rapid presumptive identification and direct demonstration of Listeria in food. Acta Microbiologica Hungarica 36, 467-471.

RuHLAND, G. J. \& FiedLeR, F. (1987). Occurrence and biochemistry of lipoteichoic acids in the genus Listeria. Systematic and Applied Microbiology 9, 40-46.

Siragusa, G. R. \& Johnson, M. G. (1990). Monoclonal antibody specific for Listeria monocytogenes. Listeria innocua, and Listeria welshimeri. Applied and Environmental Microbiology 56, 1897-1904.

TABouret, M., De RyCKe, J. \& Dubray, G. (1992). Analysis of surface proteins of Listeria in relation to species, serovar and pathogenicity. Journal of General Microbiology 138, 743-753.

Tilney, L. G. \& Portnoy, D. A. (1989). Actin filaments and the growth, movement, and spread of the intracellular bacterial parasite, Listeria monocytogenes. Journal of Cell Biology 109, 1597-1608.

Towbin, H., Staehelin, T. \& GoRdon, J. (1979). Electrophoretic transfer of proteins from polyacrylamide gels to nitrocellulose sheets: procedure and some applications. Proceedings of the National Academy of Sciences of the United States of America 76, 4350-4354.

WALKer, P. D., BATTY, I. \& Thomson, R. O. (1971). The localization of bacterial antigens by the use of the fluorescent and ferritin labelled antibody techniques. Methods in Microbiology 5A, 219-254.

WANG, R.-F., CAO, W.-W. \& Johnson, M. G. (1991). Development of a 16S rRNA-based oligomer probe specific for Listeria monocytogenes. Applied and Environmental Microbiology 57, 3666-3670.

WANNER, G., FormaneK, H., Galli, D. \& WirTh, R. (1989). Localization of aggregation substances of Enterococcus faecalis after induction by sex pheromones. Archives of Microbiology 151, 491-497. 